\title{
The End of Non-Consensual Adoption? Promoting the Wellbeing of Children in -Care
}

Authors:

Jo Ward and Joe Smeeton

Word count $6,1 \underline{6009}$

\section{Abstract}

In the UK the number of children in care has been increasing for several years; such children have backgrounds characterised by trauma, abuse and neglect. The UK is almost unique in Europe in promoting adoption for children in care. Since 2010 adoption has been promoted as a favoured means of enhancing the wellbeing of such children unable to return to their parents or birth family members, and the number of children being adopted has increased $50 \%$ in the last 2 years. Research carried out in the US and the UK has demonstrated developmental catch up and significant improvements in adopted children's physical and emotional wellbeing. However, adoption is highly contested and has come under challenge in the UK courts. This paper will link research by the two authors into this policy conflict: whether we are facing the end of adoption in the UK, and the implications for practice.

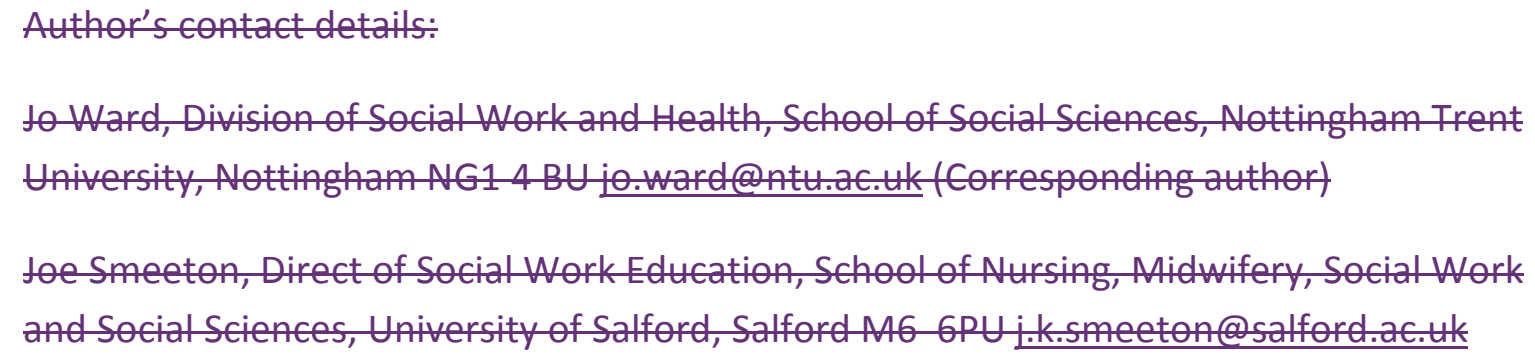




\begin{abstract}
In the UK the number of children in care has been increasing for several years; such children have backgrounds characterised by trauma, abuse and neglect. The UK is almost unique in Europe in promoting adoption for children in care. Since $\mathbf{2 0 1 0}$ adoption has been promoted as a favoured means of enhancing the wellbeing of such children unable to return to their parents or birth family, and the number of children being adopted has increased $50 \%$ in the last 2 years. Research carried out in the US and the UK has demonstrated developmental catch up and significant improvements in adopted children's physical and emotional wellbeing. However, adoption is highly contested and has come under challenge in the UK courts. This paper will link research by the two authors into this policy conflict: whether we are facing the end of adoption in the UK, and the implications for practice.
\end{abstract}

\title{
Introduction
}

This paper derives from three studies: a documentary analysis of the development of adoption in the UK from 1976 to 2000; an empirical investigation into the implementation of the UK Government's adoption reform; and a critical analysis of the treatment of birth parents within adoption in the light of recent case law.

The majority of children adopted in England and Wales come from the care system: of 5,206 children adopted in 2012, 3,470 were previously Looked After children, the remainder being primarily step - parent adoptions (Office of National Statistics 2012). Most adoptions from care are likely to be non-voluntary (Neil 2008), and the majority are 'stranger' adoptions $(85 \%)$ rather than foster carer adoptions (Selwyn, Wijedasa and Meakings 2013). Approximately $5 \%$ of children in the care system are adopted (Department for Education 2014).

In England and Wales the legal process for a child to be adopted from the care system is through a Care Order (S 31, Children Act 1989), Placement Order (S 21, Adoption and Children Act 2002) - these two orders are often made simultaneously - followed by an Adoption Order (S 46, Adoption and Children Act 2002). The Adoption Order is final and normally cannot be appealed (Case J and S, 2014). Other permanent orders which have previously been available are Special Guardianship (S 115, Adoption and Children Act 2002), and Residence Orders (S 8, Children Act 1989), now replaced by Child Arrangement Orders (S 12 Children and Families Act 2014). Only an adoption order gives full parental responsibility on a permanent basis and a lifelong legal commitment; with other orders, parental responsibility is either shared or can be revoked.

\section{What is the issue?}

Children who are looked after by the state away from their families of origin are among the most vulnerable and socially excluded in society; according to Government statistics the 
majority have been subjected to abuse, neglect and maltreatment (DfE 2014). Outcomes for children brought up in care have been of concern for several decades, both in the UK and internationally (Stein et al 2011). Currently there are 68,840 children in care in England and Wales, and the numbers have increased steadily over the last 5 years (DfE 2014). Children brought up in care are reported to have significantly worse experiences in terms of education, health, job prospects and involvement with the criminal justice system than other children, although outcomes are improving (DfE 2015). Poor outcomes are often attributed to instability within the care system (Sinclair et al 2007; Thoburn 2010).

However, there is recognition that children's pre-care experiences and complex needs also contribute to perceived poor outcomes (Berridge 2007; Bullock et al 2006). The same predictors of poor health and education also predict the need for reception into care. Ainsworth and Thoburn (2013) recognise the difficulties in comparing outcomes across European states as the make-up of the care population is very different and the types of placement in which they are cared for vary across cultures. Some states have a relatively large population of children in care compared to others and choose to use residential, foster care and kinship care in different combinations. Policy in England and Wales, and similar policy in Scotland, is to endeavour to keep children at home wherever possible or find any potential alternative to long term state care it can, through kinship care, guardianship or adoption. There is therefore a relatively small population of children in care at any one time $(0.58 \%)$ and these tend to be those with the more complex needs that cannot be met outside the care system. Many of the children whose outcomes are measured at the point of leaving care, came into care later as adolescent entrants (Sinclair et al 2007), with more complex pre care experiences and with fewer opportunities to live in permanent alternative care. The English state is indeed a reluctant parent. The state seeks to exit children from our care at every possible stage, adoption being the favoured mechanism.

The UN Convention on the Rights of the Child identifies that physical, mental (i.e. psychological), social, spiritual and moral aspects of the human being are essential for the promotion of well-being (United Nations General Assembly 1989), the psychological domain holding the "primary position in framing the quality of life and development desired for children"(Hart and Glaser 2010, 760). How far can adoption meet this need for the development of optimal well-being in children who have been maltreated?

\section{The nature and meaning of adoption}

The use of adoption places the UK in much closer alignment with the US than with European states, as outlined by the Donaldson Adoption institute. Adoption is highly emotionally charged:

In the U.S., England and Canada, where drifting through temporary situations is viewed as contrary to the best interest of children, governments are empowered to 
terminate parents' rights without their consent so that permanency can be achieved for maltreated children through adoption or guardianship (Smith 2014, 4)

Adoption rarely features in any of the European welfare regimes for children in care (Thoburn 2010). "Although the institution of the adoption of children exists in all the member states of the Council of Europe, differing views as to the principles which should govern adoption and differences in adoption procedures and in the legal consequences of adoption remain in all these countries" (European Convention on the Adoption of Children (Revised) 2008), the difference being that in almost all other European countries adoption is a consensual process, whereas in the UK parental agreement can be dispensed with (Proceedings of the Joint Council of Europe and European Commission Conference 2009). The importance of this is illustrated by the first page of the Explanatory Notes to the Education and Adoption Bill 2015 which states

Secretary of state Nicky Morgan has made the following statement under section 19(1)(a) of the Human Rights Act 1998:

In my view the provisions of the Education and Adoption Bill are compatible with the Convention rights (DfE 2015).

\section{Adoption as a route to permanence}

In England, the answer to the difficulty of securing permanence for children in the care system has long been identified as adoption. This was reinforced in 2012 by the "Action Plan for Adoption" (DfE 2012), and again since the UK general election in 2015, with the Education and Adoption Bill passing through the UK Parliament. The policy to increase the number of children being adopted was driven by the previous Secretary of State for Education, Michael Gove, an adopted person himself, and appeared in the context of a very significant increase in the number of children coming into care (CAFCASS 2012). Adoption is a highly publicised and intensely contested area of child care policy in England. The controversy has intensified since the initiative referred to above was instigated in 2012.

The key ideological stance underlying the adoption message is the following:

"Where children cannot live with their families, for whatever reason, society has a duty to provide them with a fresh start and where appropriate a permanent alternative home. Adoption is the means of giving children an opportunity to start again; for many children, adoption may be their only chance of experiencing family life";

and

"Adoption has become firmly entrenched in the social fabric since enactment of the first adoption legislation; many thousands of children have benefited from the generosity and commitment of adoptive families. Adoption is not an option of last 
resort; to regard it as such is a failure to understand the nature of adoption and its advantages for a child unable to live with his own family" (Department of Health 1998, p 2 points 3 and 4, "The benefits of adoption", our emphasis).

These statements, although dating back almost 20 years, remain the keystone of adoption policy, and the debate about whether adoption is a 'last resort' or not is resonating through the courts today.

The 2010 UK Government's commitment to adoption was set out in the following statement:

"But in many cases adoption is the best option - particularly for younger children, but also for some older children. Adoption gives vulnerable children, including many with complex needs and a history of ill-treatment, the greatest possible stability, in a permanent home with a permanent family. It is, in every sense of the word, for good" (DfE 2012, 6).

Underlying these extremely strong statements is the paradox of adoption. Adoption is more than a child welfare option. It touches on very personal and intimate issues for adults, such as infertility and personal relationships; and issues of social policy involving new family forms, and the right to be a parent. Adoption has a very powerful adult led agenda, which may or may not act in favour of children's best interests. Adoption historically was societally constructed to address issues of unmarried motherhood (for the biological mother) and infertility (for the adopting couple). It had the additional benefit that the child's origins were hidden and the child was thus saved from the stigma of illegitimacy. The idea of a 'clean break' still underlies much adoption discourse (Narey 2011) and the concept of a 'Family for Life' (for both the child and the parents) remains powerful (Smith 2014).

The concept of 'possession' of children is a key difference between the English speaking world and European social welfare norms (Lewis 2004), and is embedded in adoption discourse. The child belongs either to the birth family or the adoptive family. The adoption process sets adoptive and birth parents against each other. While the concept of 'open adoption' with contact has been accepted as an element of good practice in adoption for a number of years, this comes very late in an otherwise adversarial process, when the birth and adoptive parents have been set against each other in the court system. Adoption permanently transfers a child from one family to another: this is its attraction but therefore ethically it must be an option of last resort (Simmonds 2009).

\section{Adoption as developmental catch up}

Evidence from neuroscience increasingly confirms the impact of child maltreatment on brain development, and the subsequent effect on attachment, cognition and mental health into adulthood (evidence reviewed by Twardosz and Lutzker 2010, and Glaser 2000; see also 
Zeanah 2009). Neuroscience is also confirming the possibility of some repair if environmental conditions improve:

"The view of the brain as an organ that is continually modified by experience, not only during infancy and childhood, but throughout life, is firmly supported by research" (Twardosz and Lutzker 2010, 62); but

"Although the brain retains the ability to be changed by experience throughout life, some brain systems, such as those involved in mediating the stress response, may be much more difficult to modify than others after sensitive periods have ended" (Twardosz and Lutzker 2010, 63)

There is substantial evidence from the UK and US that adoption is beneficial for severely abused and neglected children (Dance et al 2002; Rushton and Dance 2004; Selwyn et al 2006; van ljzendoorn and Juffer 2006; Smith 2014). Longitudinal studies of children adopted from Romanian orphanages indicate that adoption can facilitate dramatic developmental catch up in both emotional and cognitive spheres (English Romanian Adoptee Study; Rutter et al 2006; Beckett et al 2006; Croft et al 2007; Chisholm 1998;. Rutter et al 2007).

Therefore, adoption must be considered as an option for such children unable to live with their birth families, in order to maximise their well- being.

Overall, adoption is successful. Rushton (2006) found that $71 \%$ of the placements of 'late placed' children were intact after 6 years, with $50 \%$ of the total being described as "happy". In Selwyn's 2006 study, only 6\% of the placements had ended 7 years after the adoption order (Selwyn et al 2006). Rushton and Dance explored the factors which encourage some parents to continue even in the face of challenges which lead them to contemplate ending the placement. These factors are:

- Disrupting the placement would be admitting defeat or failure

- It would be letting the child down and an obligation should be fulfilled

- They had bonded with the child despite the difficulties

(Rushton and Dance 2004)

This commitment to the child reinforces the earlier findings of Triseliotis that adoption confers a much stronger sense of security and belonging for the child, and a more enduring psycho-social base into adulthood than long term fostering (Triseliotis 2002).

Selwyn recently observed that disruption studies rarely distinguish between pre and post adoption order disruptions, but her recent large scale UK study found the post order national adoption disruption rate over a 12 year period to be surprisingly low, at $3.2 \%$, and lower than comparable placements, though disruptions are likely to be higher pre order, as there is movement in all types of new placement (Selwyn, Widejasa and Meakings 2013). 
Children whose adoptions disrupted were older on entering care (and thus had longer exposure to maltreatment) and were more likely to have multiple moves in the care system (Selwyn et al 2006, 2013). This research further provides evidence that the earlier a child is placed in an adoptive family, the more successful the placement is likely to be. Age is also a factor: three-quarters of the children who experienced a disruption were more than 4 years old at the time of their adoptive placement, compared with the intact group, where the majority (70\%) were under 4 (Selwyn et al 2013). McSherry and colleagues echo this although the difference in stability between adoption, kinship and birth parent placements was small, with fostering having the lowest rate for placement stability and adoption the highest (McSherry, Fargas Malet and Weatherall 2013).

\section{The effect of delay}

As has already been outlined, children who are placed for adoption come from very disadvantaged backgrounds. In 2013 the Government published research evidence in an attempt to confront the mismatch between local authority, court and children's developmental timeframes (Brown and Ward 2013). Brown and Ward suggest that while social work interventions can be effective, "the longer that children experience abuse and neglect without sufficient action being taken, the less effective are even the most intensive and intrusive interventions in promoting their long-term wellbeing" (Brown and Ward 2013, 75). In a study of infants suffering significant harm, social workers frequently postponed taking decisive action pending further assessments, and in the hope that parents would be able to overcome their difficulties; this meant that the children were further exposed to harmful maltreatment during the first formative 12 months of their lives (Ward, Brown and Westlake 2012). The study showed that:

" $93 \%(13 / 14)$ of the parents who were able to overcome adverse behaviour patterns sufficiently to provide a nurturing home did so within the first six months of the birth. Where children remained with birth parents who had not made substantial progress within this timeframe (12 cases), concerns about maltreatment persisted and were still evident at the child's third birthday. This finding has obvious implications for timescales for decision-making and for intensive interventions" (Brown and Ward 2013, 75).

Although this study involved only a small sample, it reinforces other findings. Successfully adopted children tend to be younger when they enter care and decisions about their adoption made more quickly (Selwyn et al 2006, Selwyn, Widjedasa and Meakings 2013). Repeated assessments of birth parents and family members are a major cause of delay. "Professionals encounter numerous difficulties in trying to retain a focus on the best interests of the child: attempts to ensure that parents' rights and needs are respected can conflict with those of their children" (Brown and Ward 2013, 73). Evidence of the damaging 
impact of childhood neglect and abuse into adolescence and adulthood provides a compelling case for taking early decisive action (Brown and Ward 2013).

\section{Adoption and fostering compared}

Fostering is the most usual placement for most Looked After children in the UK. Carers can be highly committed to their children and provide security and a springboard for adult life similar to a birth or adoptive family (Schofield and Beek 2000; Schofield and Beek 2005, McSherry, Fargas Malet and Weatherall 2013). But fostering is unstable - in reality children have many changes of placement (Selwyn et al 2006, Sinclair et al 2007).

Recent UK research challenges the idea that adoption, because it provides legal stability, is also more effective in bestowing emotional security for children, and argues that long term fostering can have the same beneficial effect on children's well-being (Mc Sherry, Fargas Malet and Weatherall 2013). However, for most children, fostering is not permanent. 'Permanent fostering' has no legal status. The implications of this are profound. The parenting of the child is the responsibility of the local authority, the 'corporate parent' and devolved to the social worker, not the foster carer (Hollin and Larkin 2011). The foster carer is expected to take on a semi-professional role and is viewed by social workers as having significantly less power and responsibility than birth parents (Hollin and Larkin 2011). This being the case, the relationship of nurture and support and the development of well-being is compromised by the ambiguity of the foster carer's role. Where the foster carer/child relationship does work well, it is despite rather than because of this (Oke, Rostill Brookes and Larkin 2013). Structural factors play a part: as fostering is variously categorised as 'emergency' 'short term', 'long term', children are frequently moved because of the category of placement they are in, rather than according to the needs of the child (Sinclair et al 2007)

\section{The case against adoption:}

Opposition to adoption that leads us to tentatively predict its end in the title of this paper falls within three domains that overlap to a large extent around human rights and social work values.

\section{Legal}

While the UK Government returns again and again to the use of adoption as a solution to the provision of permanent placements for children in the care of the state, and has enacted legislation and policy to promote and expedite decisions relating to adoption, recent case law seems to be pulling in the opposite direction following successful challenges in the European Court of Human Rights. Most significantly Re B-S draws our attention back to a judgement by Hale LJ Re C and B [2001] 1 FLR 611, para 34: 
"Intervention in the family may be appropriate, but the aim should be to reunite the family when the circumstances enable that, and the effort should be devoted towards that end. Cutting off all contact and the relationship between the child or children and their family is only justified by the overriding necessity of the interests of the child."

This is fortified by a judgement in the Strasbourg court YC v United Kingdom (2012) 55 EHRR 967, para 134:

"Family ties may only be severed in very exceptional circumstances and ... everything must be done to preserve personal relations and, where appropriate, to 'rebuild' the family. It is not enough to show that a child could be placed in a more beneficial environment for his upbringing."

The judgement leaves us in no doubt about its opinion that the court should assure itself that the local authority responsible for the provision of services have explored and exhausted all the alternative ways to support and protect the child, short of applying for orders contemplating non-consensual adoption which, to be made "only in exceptional circumstances and where motivated by overriding requirements pertaining to the child's welfare, in short, where nothing else will do" (Sprinz 2014)

Social workers are acutely aware of the most prominent principle of the Children Act (1989) that the child's interests should be the paramount consideration. This judgement reminds us that those interests include being brought up by the birth family unless the overriding requirements of the child's welfare make that not possible (Sprinz 2014). Where it is not possible the court must consider all the other potential options for caring for the child. English law isn't short of alternatives including Family Assistance Orders, Supervision Orders, Child Arrangement Orders, Special Guardianship Orders; all of which allow for placement with relatives or the extended family, with foster carers, or in a range of specialist residential provision within health or social care. Before courts can make placement or adoption order they must therefore be satisfied that the social workers requesting the order can provide evidence of the lack of alternative options and an analysis that allows the court to conclude that nothing short of adoption is appropriate.

Bainham \& Markham $(2014,1002)$ suggest a philosophical gulf between this and the views of Sir Martin Narey, whose report had a major influence on the Government. According to Narey: 'No-one disputes that adoption offers the most stable and secure environment for a child who can no longer live with his or her own parents, but too few are being given this chance.' (Narey 2011, 2). This policy view is a long way from judgments that adoption should be used as a 'last resort'.

While the UK government is enacting legislation to promote adoption it is also enacting legislation that potentially acts against that stated aim. S.9 of the Children \& Families Act 
(2014) amends the Adoption and Children Act (2002) to include S.51a which enables the court to make an order in favour of post-adoption contact at the time of the making of the adoption order or, at any time afterwards, in favour of:

(a) any person who (but for the child's adoption) would be related to the child by blood (including half-blood), marriage or civil partnership;

(b) any former guardian of the child;

(c) any person who had parental responsibility for the child immediately before the making of the adoption order;

(d) any person who was entitled to make an application for an order under section 26 in respect of the child (contact with children placed or to be placed for adoption) by virtue of subsection (3)(c), (d) or (e) of that section;

(e) any person with whom the child has lived for a period of at least one year.

Potential adopters then are faced with the prospect that any of the above can at any time, apply for contact with the child they have adopted. Applicants who can convince the court that an application would not risk disrupting the child's life 'to such an extent that he or she would be harmed by it (within the meaning of the 1989 Act)' are likely to get leave to make the application $(\mathrm{S} .51 \mathrm{a}, 4)$. This potentially changes the 'permanent' nature of adoption to one of uncertainty that leaves a door open for anyone from the child's pre-adoption history to apply for contact with the child. How often such orders will be made by UK courts remains to be seen, however we are still discovering the unfolding capacity for social media to facilitate unplanned and unsupervised contact between adopted children and their birth families, which could ultimately negate the need for courts to rule on such arrangements (MacDonald and McSherry 2013).

\section{Ethical}

A major driver of the Children \& Families Act (2014) is to foreshorten the length of time that care proceedings take and imposes a time-limit that proceedings, including consideration of adoption, should be completed within 26 weeks. Shaw et al (2014a) in their seminal study of birth parents who suffer recurrent removals of children through the family court, point out that decisions are made within the child's timescales and the court's timescales and ask the question, "But what about the parent's timescales?" suggesting that an intervention of at least 3 years would be indicated for ongoing work with birthparents. Featherstone, White and Morris (2014) argue that the emergence of arbitrary timelines for care planning and rise of actuarial tools to measure parental capacity with time-limited opportunities for change are, ultimately, concerned with a privileging of child removal and adoption as a preferred outcome for children experiencing risk and harm. They argue that adoption without consent 
reinforces the temporal pressures on decision makers and artificially delimits consideration of support for families. Birth parents are faced with having very little time to overcome significant challenges in their lives in order to meet the courts timescales. Booth, McConnell and Booth (2005) described parents with learning disabilities as facing temporal discrimination as they are by nature unable to learn how to parent quickly enough.

This 'rush' towards adoption with the purpose of finding a forever family as soon as possible, mean that birth parents' rights, needs and vulnerabilities are being neglected in the process.

"Anecdotal evidence suggests that following the compulsory removal of children, the plight of birth mothers all too easily falls outside service provision, leaving women to make their own sense of the lifestyle and relationship circumstances that have led to compulsory child protection intervention" (Broadhurst and Mason 2013)

Many of these mothers face recurrent removals of children in subsequent care proceedings and there is a growing moral concern that this may be due to the iatrogenic effects of compulsory legal proceedings (Broadhurst and Mason 2013). The argument is beginning to emerge that the process of compulsory adoption is further damaging already vulnerable people. Some authors have talked about the negative impacts upon parents of having a child removed from their care, often with complex feelings of stigma, guilt and shame (Wells 2011; Clifton 2012; Buckley, Carr and Whelan 2011) and how this damages their ability to trust and work with social workers after feeling tricked or betrayed by them (Smeeton and Boxall 2011; Palmer, Maiter and Manjii 2006). Wells (2011) cites Twenge and Baumeister, (2005) in arguing that the stigma that arises from loss of children can be demonstrated to increase aggression and self-defeating behaviour. She believes that shame's consequence is a sense of worthlessness. Neil's (2013) ongoing longitudinal study into adoption has uncovered very high levels of psychological distress experienced in birth relatives, $56.7 \%$ of whom had overall scores within the clinical range believing however that this might be an underestimate.

Scaife (2013) argues that many of the social work assessments that are put before courts are "disproportionately deficit focused" arguing that it can be very difficult for social workers to be seen to undertake fair assessments of parenting while concurrently planning the compulsory adoption of the child. Parents then are often faced with a catalogue of their deficits and little recognition of their strengths (Smeeton and Boxall 2011)

Clifton (2012) highlights the particular systemic disadvantage faced by birth fathers and the impacts upon their emotional well-being of the related, but distinct, feelings of guilt and shame induced by the forced adoption of their children. Birth fathers are often completely excluded from adoption proceedings. Masson, Pearce and Bader (2008) recorded that only $34 \%$ of birth fathers were accorded party status in proceedings and Clapton (2014) 
concludes that in the majority of cases they don't even feature on the original birth certificate.

Many of these birth parents whose rights and capacity for change we dismiss so easily are in fact still very young. Shaw et al (2014b) noted in their feasibility study that $37 \%$ of all mothers whose children were removed were aged between 14 and 24 years. Broadhurst and Mason $(2014,1576)$ suggest that they shouldn't be considered beyond redemption and that initial observations from their pilot study “...resonate with a broader literature, which suggests that resilient functioning can be nurtured later in the life cycle, rather than simply in childhood/adolescence."

\section{Empirical}

Another challenge to adoption as a preferred disposal is beginning to emerge from the empirical evidence.

In a comparison of adoption, special guardianship and residence orders, Selwyn and Masson $(2014,1714)$ assert that their findings should... "dispel misconceptions about the fragile nature of adoption." They state that "for the vast majority of children who were adopted, the placement endured; adoptive parents were committed and tenacious, despite experiencing difficulties during their children's teenage years". However, we must question whether this is due to the adoption per se or rather that children who are most likely to have successful long-term placements tend to be placed for adoption rather than in foster care because they are generally younger, with a less complicated pre-care experience and with fewer placement moves while in care. It could be argued that while adopters are increasingly accepting harder to place children, adoption as an approach in effect "cherry picks" children who are likely to settle well into placement.

The DfE's Statistical First Release (2013) recognizes that the achievements and outcomes gaps between looked after children and the general population are closing but that looked after children still face significant challenges. This is often taken to reflect a failing care system rather than recognition that the needs of children who are looked after are often very complex. Forrester et al $(2009,450)$ argue that "Only adoption in early childhood offers a realistic prospect for most children of achieving welfare outcomes at a similar level to the general population." But Forrester et al also found that there is little evidence that the care system has a negative impact upon children's welfare. In their review of the literature they found that children's welfare improved in almost all of the studies and there was none in which it deteriorated. They argue that public care should be seen as a way of supporting families rather than seeking permanent alternatives to its use.

The argument that adoption is necessarily better than foster care continues to be challenged. Outcomes for children are subject to many complex and interacting variables and that the more complex the placement circumstances, the more difficult it is to attribute success to any one factor or type of placement (Sellick, Thoburn and Philpot 2004). They argue that timescales are important, and the measurement of long-term outcomes is 
particularly challenging. When age at placement and other variables are held constant, there are no differences in breakdown rates between adoptive placements and placements with permanent foster families. Some children prefer to be fostered and others prefer to be adopted. Long-term placement with relatives or friends ('kinship care'), and short-term placements that become permanent, have though been found to be more successful for the full range of children than placement with families not previously known to the child ('stranger care').

Neil, Beek and Ward (2014) report that researcher ratings identified half of the young people in their longitudinal study of adoption as "thriving" overall whilst the remainder were either "surviving" or "struggling" suggesting that adoption can provide stability and a loving family base for children who have experienced early adversity in life, although many children are also likely to have ongoing support needs. However, if an adoption does disrupt, this has a devastating effect on their emotional and psychological well being (Selwyn, Widjedasa and Meakings 2013). Is it worth the risk?

"Where benefits accrue from adoption this may in part result from the greater security that adopters experience in acting autonomously in the best interests of the children for whom they provide a home" (Selwyn and Quinton, 2004 cited in Scaife 2013, 231). Children's sense of security is built upon that of the carers. On this dimension, adopters are in a privileged position compared with foster carers (Scaife, 2013). If as we have argued above this security is undermined by legislative changes and the increasing impact of social media, what is left of the claims for adoption's outcomes?

\section{Conclusions and implications for practice}

Evidence shows that adoption can be beneficial to children's well-being when they have been maltreated in early life. Adopted children generally achieve developmental catch up in cognitive, emotional and psycho social spheres. Most adoptions endure, at least half of them happily, and when this happens adoption provides security, stability and life- long commitment - a family for life.

The issue is whether other forms of placement can do this, and if so whether such placements should be promoted at least as vigorously as adoption. Even more importantly, do the deleterious long term effects on birth parents from non-consensual adoption make such adoption ethically untenable; or do the long term benefits to the child outweigh such qualms?

This is a fundamental debate about birth parent rights $v$ child's rights, and exposes an underlying philosophical difference within social work. The evidence presented above about the long lasting deleterious effects of enforced adoption, although in one sense this 
has long been known (Howe, Sawbridge and Hinings 1992) raises fundamental questions about the Government's pursuit of adoption at almost any cost.

In an ideal world parents who are struggling to provide adequate care for their children to such an extent that the children are likely to be removed, would receive appropriate intensive intervention within an appropriate timescale so that informed decisions can be made about the child's future, taking into account the child's developmental needs. We would see intensive support for birth parents whose children have been adopted, to prevent further damage to already vulnerable people and to enable them to keep subsequent children. This should be provided as a matter of course, not in a mythical ideal world, as in addition to the improved well-being for both parent and child, it would have economic benefits too. But there are factors in the real world which impinge on the ideal. If the child's situation at home is such that they have to be removed, and delay is damaging to children's future development, how long should the child wait? The parents' timescale, suggested at three years by Shaw, is a very long time in child development terms.

However, the nature of adoption is changing. The legal acknowledgement of the importance of contact, and its development in practice through social media, will undermine traditional views of adoption, and might make adoption more acceptable and therefore more likely. If adoption becomes more like long term fostering ought to be, i.e. legally permanent so that carers have full parental responsibility, but retaining or promoting psychological and communicative openness towards birth parents (Neil and Howe 2004), this might offer a convergence of the two dialectical positions.

Reviewing the case for adoption on legal, ethical and empirical grounds suggests that we need to rethink alternative forms of out-of-home care, perhaps by developing the use of other orders, or fortifying the status of fostering to enable foster carers to act autonomously for the children in their care. Perhaps we should revert to use of the term 'foster parent'. In light of these challenges it is hard to sustain an argument that birth parent's rights should continue to be ridden over in such a roughshod way by the system. However, the very presence of adoption as a preferred outcome skews practice throughout the system and changes the capacity for social workers to engage with birth parents in a constructive mode. Adoption seems to function in a risk-focused system as the least risky option for children and for decision-makers. Working within the risk paradigm though is beginning to be challenged and shifting practice back towards 'care', which aims to build, not break, relationships between parents and their children and between families and social workers. We seem stuck in Fox-Harding's state paternalism and child protection perspective, rescuing children from their parents (Fox Harding 1997). Shaw et al (2014b 1707 ) believe that current practice that relies on "...coercion needs to be balanced by something more therapeutic..." that leaves room for optimism and hope that families can change and not be torn apart by the courts. 
The debate as to how permanence should be formulated has never been openly rehearsed until now. Despite the fact that adoption only affects a small number of children, it has continued to push out alternative discourses. The idea of adoption as a 'happy ever after' story has a very powerful emotional pull, despite its obvious complexities. Adoption remains a beacon of hope and simplicity in a complex child welfare world. Children can be rescued, initially from their birth family, then from the life 'languishing in care' originally described by Rowe and Lambert (1974), through the apparently simple outcome of adoption. Other forms of permanence are more complicated and messy, and not permanent enough. But legislative, social and cultural changes imply that adoption is becoming more like long term fostering - for this to work for all parties it needs to be secure and life-long for foster/adoptive parents and child, but with emotional and physical openness to birth parents. 'Open adoption', long talked about but rarely implemented in its true sense, may become the reality. If so, this can only be good for children's wellbeing.

In conclusion, we cannot but help agreeing with the claim that:

"Social Work must, fundamentally, be an empirical profession. Compassionate and empirical. Social Workers must attend to furthering their understandings of the particular family and individuals immediately before them, rather than glossing families into spurious universals and institutional categories. This requires both rigour and humility." (Featherstone, White and Morris 2014, 153)

\section{Afterword}

Writing this paper has exposed us to strong feelings about the nature of social work and practice with parents and children to a much more profound level than we had anticipated. We remain respectful of each other's viewpoint and also remain committed to finding the best outcomes for children. 


\section{References: The End of Non - Consensual Adoption? Adoption as a Means of Promoting the Wellbeing of Children in the Care of the State}

Ainsworth, F. \& J. Thoburn 2014. "An Exploration of the Differential Usage of Residential Childcare Across National Boundaries". International Journal of Social Welfare 23:16-24

Bainham, A. \& H. Markham 2014. "Living With re B-S: Re S and its Implications for Parents, Local Authorities and the Courts". Family Law Journal 44 (7): 931-1088

Beckett, C., B. Maughan, M. Rutter, J. Castle, E. Colvert, C. Groothues 2006. "Do the Effects of Early Severe Deprivation on Cognition Persist into Early Adolescence? Findings from the English and Romanian Adoptees Study. Child Development, 77: 696-711.

Berridge, D. 2007. Theory and Explanation in Child Welfare: Education and Looked After Children. Child \& Family Social Work, 12: 1-10

Bullock, R., M.E. Courtney, R. Parker, I. Sinclair, and J. Thoburn 2006. "Can the Corporate State Parent?" Adoption \& Fostering 30 (4):6-19

Brown, R. and H. Ward 2013. "Decision Making within a Child's Timeframe", Child Wellbeing Research Centre https://www.gov.uk/government/publications/decision-makingwithin-a-childs-timeframe-an-overview-of-current-research-evidence-for-family-justiceprofessionals-concerning-child-development-and accessed 13th July 2015

Booth, T., D. McConnell, \& W. Booth 2006. "Temporal Discrimination and Parents with Learning Difficulties in the Child Protection System". British Journal of Social Work 36: 9971015

Broadhurst, K. and C. Mason 2013. "Outcasts: Raising the Profile of Women Who Are Vulnerable to Successive, Compulsory Removals of Their Children". Journal of Social Welfare and Family Law 35 (3): 291-304 http://dx.doi.org/10.1080/09649069.2013.805061

Broadhurst, K. and C. Mason 2015. "Recurrent Care Proceedings: Part 3: Birth Mothers Against the Odds: Turning Points for Women Who Have Lost Children to Public Care". Family Law 44(11):1572-1576

Buckley, H., N. Carr and S. Whelan 2011. "Like Waking Up in a Franz Kafka novel: Service Users Experiences of the Child Protection System when Domestic Violence and Acrimonious Separation is Involved". Children and Youth Services Review 33(1):126- 133

CAFCASS (Child and Family Courts Advisory Service) 2012. "Three Weeks in November, Three Years On: CAFCASS Care Applications Study 2012", http://www.cafcass.gov.uk/media/6455/Cafcass\%20Care\%20study\%202012\%20FINAL.pdf accessed $14^{\text {th }}$ July 2015 
Case J and S, 2014 England and Wales Family Court Decisions (High Court Judges) http://www.bailii.org/ew/cases/EWFC/HCJ/2014/4.html accessed 13th July 2015

Chisholm, K. 1998. A three year follow-up of attachment and indiscriminate friendliness in children adopted from Romanian orphanages. Child Development, 69, 1092-1106.

Clapton, G. 2014. "The Birth Certificate: Father Unknown” Adoption \& Fostering 38(3): 209222

Clifton, J. 2012. "Birth Fathers and Their Adopted Children: Fighting, Withdrawing or Connecting". Adoption \& Fostering 6 (2):43-56

Croft, C., C. Beckett, M. Rutter, J. Castle, E. Colvert, C. Groothues 2007.

"Early Adolescent Outcomes of Institutionally-Deprived and Non-Deprived Adoptees.

II: Language as a Protective Factor and a Vulnerable Outcome. Journal of

Child Psychology and Psychiatry, 48: 31-44.

Dance, C., A. Rushton, and D. Quinton. 2002. "Emotional Abuse in Early Childhood:

Relationships with Progress in Subsequent Family Placement", Journal of Child Psychology and Psychiatry 43: 395-407

Department for Education 2012. "Action Plan for Adoption"

https://www.gov.uk/government/publications/an-action-plan-for-adoption-tackling-delay Accessed 14th July 2015

Department for Education 2013. "Children in Care" http://www.education.gov.uk/childrenandyoungpeople/families/childrenincare Accessed $14^{\text {th }}$ July 2015

Department for Education 2014. Children Looked After in England including Adoption https://www.gov.uk/government/uploads/system/uploads/attachment data/file/359277/S FR36 2014 Text.pdf Accessed 14 ${ }^{\text {th }}$ July 2015

Department of Education 2015. Education and Adoption Bill http://services.parliament.uk/bills/2015-16/educationandadoption.html Accessed 4th January 2016

Department of Health 1998. Local Authority circular 98(20) "Adoption: Achieving the Right Balance", http://webarchive.nationalarchives.gov.uk/+/www.dh.gov.uk/prod consum $\mathrm{dh} / \mathrm{groups} / \mathrm{dh}$ digitalassets/@dh/@en/documents/digitalasset/dh 4011200.pdf Accessed 14 ${ }^{\text {th }}$ July 2015

Education and Adoption Bill 2015. http://services.parliament.uk/bills/2015-

16/educationandadoption.html Accessed 14th July 2015 
English Romanian Adoptee Study http://www.nuffieldfoundation.org/english-andromanian-adoptee-study Accessed 13th July 2015

European Convention on the Adoption of Children (Revised) 2008. http://conventions.coe.int/Treaty/en/Treaties/Html/202.htm Accessed 14 ${ }^{\text {th }}$ July 2015

Featherstone, B. S. White and K. Morris 2014. Re-imagining Child Protection: Towards Humane Social Work with Families. Bristol: Policy Press

Forrester, D., K. Goodman, C. Cocker, C. Binnie \& G. Jensch 2009. "What is the Impact of Public Care on Children's Welfare? A Review of Research Findings from England and Wales and their Policy Implications." Journal of Social Policy, 38:439-456

doi:10.1017/S0047279409003110

Fox - Harding, L. 1997. "Perspectives in Child Care Policy”, London: Routledge.

Glaser, D. 2000. "Child Abuse and Neglect and the Brain: a Review", Journal of Child Psychology and Psychiatry, 41 (1):97-116

Hart, S. and D. Glaser 2011. "Psychological Maltreatment - Maltreatment of the Mind: A Catalyst for Advancing Child Protection Toward Proactive Primary Prevention and Promotion of Personal Well-being", Child Abuse and Neglect (35): 758 -766

Hollin, G. and M. Larkin 2011. "The Language and Policy of Care and Parenting: Understanding the Uncertainty About Key Players' Roles in Foster Care Provision" Children and Youth Services Review, 33: 2198 -2206

Howe, D., P. Sawbridge and D. Hinings 1992. "Half a million women: mothers who lose their children through adoption", London: Penguin.

Ivaldi, G. 2000. "Surveying Adoption: A Comprehensive Analysis of Local Authority Adoptions 1998 -1999 (England)". London: BAAF

Jones, C. and S. Hackett 2011. "The Role of Family Practices and Displays of Family in the Creation of Adoptive Kinship", British Journal of Social Work 41:40 -56

Lewis J. 2004. "Adoption, the Nature of Policy Shifts in England and Wales, 1972 - 2002", International Journal of Law, Policy and the Family, 18:235 -255.

MacDonald, M. and D. McSherry 2013. "Constrained Adoptive Parenthood and Family Transition: adopter's experience of unplanned birth family contact in adolescence." Child \& Family Social Work 18: 87-96.

Marshall P. \& N. Fox (Ed) "The Development of Social Engagement: Neurobiological Perspectives". New York: Oxford University Press.

Masson, J., J. Pearce and K. Bader 2008. Care Profiling Study. Bristol: Ministry of Justice 
McSherry, D. and M. Fargas Malet 2013. Comparing Long Term Placements for Young Children in Care: The Care Pathway and Outcomes Study - Northern Ireland, London: BAAF

Narey, M. 2011. “Adoption: a Blueprint for a Lost Generation". The Times, July 5, 2011. Available at http://www.mnarey.co.uk/adoption-advisor.php Accessed $14^{\text {th }}$ July 2015

Neil, E. 2008. "Coming to Terms with the Loss of a Child", Adoption Quarterly 10 (1):

Neil, E. 2012. "Making Sense of Adoption: Integration and Differentiation from the Perspective of Adopted Children in Middle Childhood" Children and Youth Services Review 34: 409-416

Neil, E. and D. Howe. 2004. "Contact in Adoption and Permanent Foster Care". London: BAAF.

Neil, E. M. Beek, and E. Ward. 2014. "Contact After Adoption: A Longitudinal Study of Adopted Young People and their Adoptive Families and Birth Relatives". London: BAAF

Office of National Statistics, Adoptions in England and Wales 2012, http://www.ons.gov.uk/ons/rel/vsob1/adoptions-in-england-and-wales/2012/stbadoptions-in-england-and-wales--2012-.html

Accessed $14^{\text {th }}$ July 2015

Oke, N., H. Rostill Brookes and M. Larkin 2013. "Against the Odds: Foster Carers Perceptions of Family, Commitment and Belonging in Successful Placements". Clinical Child Psychology and Psychiatry 18 (1):17 -24

Palmer S., S. Maiter \& S. Manji 2006. "Effective intervention in child protective services: Learning from parents" Children and Youth Services Review 28:812-824

Proceedings of the Joint Council of Europe and European Commission Conference (2009) "Challenges in adoption procedures in Europe: Ensuring the best interests of the child" Strasbourg: European Commission for Justice http://ec.europa.eu/justice/civil/files/brochure conference adoption en.pdf Accessed $14^{\text {th }}$ July 2015

Quinton, D., A. Rushton, C. Dance, and D. Mayes 1998. Joining New Families: A Study of Adoption and Fostering, Chichester: Wiley,

Rushton, A. 2004. "A Scoping and Scanning Review of Research on the Adoption of Children Placed from Public Care". Clinical Child Psychology and Psychiatry, 9: 89-106

Rushton, A. and C. Dance, 2004. "The Outcomes of Late Permanent Placements: The Adolescent Years" Adoption and Fostering 28: 49

Rutter, M. 2006. "The Psychological Effects of Institutional Rearing". In Marshall P. \& N. Fox (Ed), "The Development of Social Engagement: Neurobiological Perspectives". New York: Oxford University Press. 
Rutter, M., E. Colvert, J. Kreppner, C. Becket, J. Castle and G. Groothues 2007.

"Early Adolescent Outcomes for Institutionally-Deprived and Non-Deprived Adoptees.

I: Disinhibited Attachment". Journal of Child Psychology and Psychiatry, (48): 17-30.

Scaife, J. 2013. Deciding Children's Futures: An Expert Guide to Assessments for Safeguarding and Promoting Children's Welfare in the Family Court Hove: Routledge

Schofield, G. and M. Beek. 2000. Growing Up in Foster Care, London: BAAF.

Schofield G. and M. Beek. 2005. "Providing a Secure Base: Parenting Children in Long Term Foster Family Care", Attachment and Human Development (7):1

Schofield G. and M. Beek. 2009. "Growing Up in Foster Care: Providing a Secure Base Through Adolescence", Child and Family Social Work (14) :255-266

Sellick, C., J. Thoburn and T. Philpot 2004. "What Works in Adoption and Foster Care". Ilford: Barnardos

Selwyn J., W. Sturgess, D. Quinton, and C. Baxter 2006. The Costs and Outcomes of NonInfant Adoptions, London: BAAF

Selwyn, J., D. Wijedasa, and S. Meakings 2014. Beyond the Adoption Order: Challenges, Interventions and Adoption Disruption. Research Report University of Bristol School for Policy Studies Hadley Centre for Adoption and Foster Care Studies, 2014 https://www.gov.uk/government/uploads/system/uploads/attachment data/file/301889/F inal Report - 3rd April 2014v2.pdf Accessed 14th July 2015

Selwyn, J. and J. Masson 2014. "Adoption, special guardianship and residence orders: a comparison of disruption rates" in Family Law 44(12): 1709-1714

Shaw, M., K. Broadhurst, J. Harwin, B. Alrouh, S. Kershaw, and C. Mason 2014a. "Recurrent Care Proceedings: Part 1: Progress in Research and Practice since the Family Justice Council 6th Annual Debate". Family Law 44(9): 1284-1287

Shaw, M., K. Broadhurst, J. Harwin, B. Alrouh, S. Kershaw, and C. Mason 2014b. "The Emergence of Child Protection as a Public Health Issue: How Would a More Preventionoriented Approach Alter the Provision of Services and the Family-Professional Relationship?" Family Law 44(12):1705-1708

Sinclair, I. C. Baker, J. Lee, and I. Gibbs 2007. The Pursuit of Permanence: a Study of the English Child Care System, London: Jessica Kingsley

Smeeton, J. and K. Boxall 2011. "Birth Parents Perceptions of Professional Practice in Child Care and Adoption Proceedings: Implications for Practice" Child and Family Social Work 16(4):444 -453 
Smith, S. "A Family for Life: Compendium of Effective and Promising Practices for Facilitating Adoptions from Foster Care", Donaldson Adoption institute, 2014, summarised at http://adoptioninstitute.org/wordpress/wpcontent/uploads/2014/01/2013 04 FamilyForLife.pdf Accessed 14th July 2015

Sprinz, L. 2014. “Adoption in 2014" Family Law 44(3): 257-392

Stein, M., H. Ward, and M. Courtney 2011. "Editorial: International Perspectives on Young People's Transitions from Care to Adulthood"', Children and Youth Services Review, 33(12): 2409-11.

Thoburn J. 2010. "Achieving safety, stability and belonging for children in out-of- home care: the search for what works across national boundaries", International Journal of Child and Family Welfare 1-2: $34-49$

Triseliotis, J. 2002."Long term foster care or adoption: the evidence examined", Child and Family Social Work, 7: 23 -33

Twardosz, S. and J.R. Lutzker 2010. "Child Maltreatment and the Developing Brain - a Review of Neuroscience Perspectives" Aggression and Violent Behaviour, 15:59 68

Van IJzendoorn, M. H. and F. Juffer 2006. “Adoption as intervention. Meta-analytic evidence for massive catch-up and plasticity in physical, socio-emotional, and cognitive development" Journal of Child Psychology and Psychiatry 47: 1228-1245

Ward, H. and R. Brown 2013. "Decision Making within a Child's Time Frame " Child Wellbeing Research Centre https://www.gov.uk/government/publications/decisionmaking-within-a-childs-timeframe-an-overview-of-current-research-evidence-for-familyjustice-professionals-concerning-child-development-and Accessed 14th July 2015

Ward, H. R. Brown and D. Westlake. 2012. "Safeguarding Babies and Very Young Children from Abuse and Neglect". London: Jessica Kingsley

Wells, K. 2011. "A Narrative Analysis of One Mother's Story of Child Custody Loss and Regain" Children and Youth Services Review 33: 439-447

Zeanah, C. 2009. "The Importance of Early Experiences: Clinical, Research and Policy Perspectives", Journal of Loss and Trauma, 14: 266 - 279

RE B - S (Children) (2013) EWCA Civ 1146 http://www.familylawweek.co.uk/site.aspx?i=ed117048 accessed $14^{\text {th }}$ July 2015 